\section{Prevalence of multiple sclerosis in the city of Santos, SP}

\author{
Prevalência de esclerose múltipla na \\ cidade de Santos, SP
}

Yara Dadalti Fragoso

Maristela Peres

Department of Neurology, Medical Faculty, Universidade Metropolitana de Santos and Reference Center for Multiple Sclerosis for the coastal region of the State of São Paulo, Brazil.

Correspondence: Yára Dadalti Fragoso. Department of Neurology, Medical Faculty UNIMES. Rua da Constituição 374, CEP 11015-470, Santos SP, Brasil. Phone/fax: +55 13 32263400. e-mail: yara@bsnet.com.br

\section{Resumo}

Objetivo: Estudar a prevalência da esclerose múltipla (EM) no município de Santos, SP. Metodologia: Análise dos dados do Centro de Referência em EM do Litoral Paulista, da Associação de Portadores de EM da Baixada Santista (APEMBS), com participação ativa de todos os neurologistas e neurocirurgiões da cidade, dados do IBGE, dados da Prefeitura Municipal de Santos, dados do EMPLASA. Foi usado o método proposto pelo BCTRIMS (já utilizado em outros estudos semelhantes) para coleta e análise de dados, sendo 30 de junho de 2005 o dia da prevalência. Resultados: Santos tem uma área de 280,3 $\mathrm{km}^{2}$, com 418.316 habitantes (1,49 habitantes por $\mathrm{km}^{2}$ ). Foram identificados 65 pacientes, dando um índice de 15,54/100.000. O sintoma inicial mais freqüente foi neurite óptica $(28,8 \%)$. Conclusão: os dados no município de Santos são semelhantes aos já registrados porém não publicados de outras cidades do estado de São Paulo e do Brasil.

Palavras-chave: Esclerose múltipla. Prevalência. 


\section{Abstract}

Objective: To assess the prevalence of multiple sclerosis (MS) in the city of Santos, SP. Method: Evaluation of data from the Reference Center for MS of the coastal region of the State of São Paulo, from the Regional Association of Patients with MS (APEMBS), with active participation of all neurologists and neurosurgeons of the city, data from IBGE, from the city council, and from EMPLASA. The protocol proposed by the BCTRIMS (already used in other similar studies) was used for data collection and analysis, June $30^{\text {th }} 2005$ being established as the prevalence day. Results: Santos has an area of $280.3 \mathrm{~km}^{2}$, with 418,316 inhabitants (1.49 inhabitant per $\mathrm{km}^{2}$ ). A total of 65 patients were identified, attaining the prevalence of $15.54 / 100.000$. The most frequent initial symptom of the disease was optical neuritis (28.8\%). Conclusion: data from the city of Santos are similar to those already observed, but as yet not published, in other cities of the State of São Paulo and of Brazil.

Keywords: Multiple sclerosis. Prevalence.

\section{Introduction}

Multiple sclerosis (MS) is a T-cell immune-mediated disease characterized by demyelization of the central nervous system (CNS). The typical course of the disease presents recurrent episodes of neurological dysfunction that reflect immunological alterations. Variable degrees of relative clinical remission are associated with clinical bouts of the disease. The neurological symptoms of the disease are manifestations of the inflammatory reaction of the CNS and, over the long term, they reflect the degenerative aggression against a variety of functional neurological systems $^{1,2}$. MS seems to be a relatively rare disease in South America, in comparison with Northern hemisphere countries ${ }^{3}$.

Few studies have been carried out in South America regarding the epidemiology of MS. A large effort currently underway, organized by the Latin American Committee for Research and Treatment of Multiple Sclerosis (LACTRIMS) ${ }^{4}$ aims to fill the gap in the knowledge of this disease. Led by the Brazilian Committee for Research and Treatment of Multiple Sclerosis (BCTRIMS) $)^{5}$, several Latin American countries are now starting to present their epidemiological data at conferences, although publications are still scarce.

MS can follow very different development patterns and variable rates of disability accumulation, which usually makes early and precise diagnosis difficult ${ }^{6}$. It is typically a disease of young adults, and early diagnosis is essential for appropriate treatment.

Therefore, it is very important to start to present data on the epidemiology of MS in our country, since this is the most common cause of disability in young people in several countries where its prevalence and incidence have been assessed ${ }^{3,7}$. The present paper reports on the prevalence of MS in the city of Santos, SP, Brazil, and was carried out under the strict BCTRIMS protocol ${ }^{5}$. 


\section{Methods}

Multiple Sclerosis was diagnosed according to the Poser $^{8}$ and Mc Donald ${ }^{9}$ criteria. Data were collected from the database of the Reference Center for Multiple Sclerosis of the coastal region of the State of São Paulo, which includes the city of Santos. In addition, the Regional Association of MS Patients (APEMBS) collected data from possible cases among the Association's members that had not been registered in the Reference Center by these individuals' own choice. Such patients had usually been diagnosed in larger cities such as São Paulo, SP, and preferred to continue their treatment there. Although they were living in Santos, they used the addresses of relatives in those cities in their registrations. All neurologists and neurosurgeons in Santos were invited to forward their cases to us, and a special meeting at the Santos Medical Association was organized for data collecting. Data were also collected from the Brazilian Institute of Geography and Statistics (IBGE), from the city council of Santos, and from the São Paulo Company for Metropolitan Planning (EMPLASA). The prevalence day for collection and data analysis was June 30, 2005.

\section{Results}

Santos has an area of $280.3 \mathrm{~km}^{2}$, with an urban area of $99.47 \%$, and 418,316 inhabitants (1.49 inhabitants per $\mathrm{km}^{2}$ ) estimated on the prevalence day. This population mainly comprises Caucasians (77\%), Mulattoes (21\%) and people of unmixed African origins $(2 \%)$, with a literacy level of $96.6 \%$. The city is located at a latitude of $23^{\circ} 57^{\prime} 35^{\prime \prime} \mathrm{S}$, longitude of $46^{\circ} 19^{\prime} 56^{\prime \prime} \mathrm{W}$, and its mean altitude is $10 \mathrm{~m}$. It has a typically tropical transitional coastal climate, with an average annual temperature of $20^{\circ} \mathrm{C}$ and average annual rainfall of $1,500 \mathrm{~mm}$. There are eight hospitals in the city (one public hospital, two private hospitals with beds for the national health system, and five exclusively private hospitals), two laboratories able to perform complete spinal fluid analyses and three apparatus for magnetic resonance imaging (MRI). These laboratories and MRI imaging are both for public and private use.

A total of 59 MS cases were identified in the Reference Center. All patients treated by the neurologists and neurosurgeons in the city were registered in the center. These 59 patients comprised 48 females and 11 males, thereby giving a prevalence of 14.1/100,000 inhabitants. APEMBS identified other four patients with confirmed MS who had chosen not to register in the Reference Center ( 2 females and 2 males). The patients attending the Reference Center informed us of other two patients (both males with confirmed MS) who were undergoing treatment in São Paulo and were not registered in their city of residence, but were using addresses of relatives in the city of São Paulo.

Thus, a total of 65 cases were identified among the inhabitants of the city of Santos, attaining a prevalence of 15.54/100,000 inhabitants.

Data from the patients who were not registered in Santos cannot be presented. However, when considering only the 59 cases with complete data, a clear predominance of the Caucasian ethnic group (88\%), high level of schooling (49\%), clinical presentation of relapsing-remitting MS (RRMS) (69.5\%), with no or minimal symptoms of disability (59.3\%) was observed. The most frequent symptom in the initial presentation of the disease was optical neuritis $(28.8 \%)$, followed by motor (18\%) or sensitive (18\%) symptoms. The average time elapsed between initial symptoms and diagnosis was three years. The average age at the time of diagnosis was 32 years (range $=14$ to 64 years). The initial diagnosis was obtained from neurologists working for the public health service in 11 cases, by the Reference Center in Multiple Sclerosis of the coastal region of the state of São Paulo in 32 cases, and by private neurologists in 16 patients.

\section{Discussion}

MS is typically a chronic disease and 
the results from its treatment with diseasemodifying immunomodulators are not curative. However, there is evidence from several clinical trials that such immunomodulators may delay the progression of the disease, although the results may be sub-optimal with such treatments ${ }^{10}$, especially if therapy is started late in the course of MS. It is essential that patients receive early diagnosis in order to have potentially better results from immunomodulatory drugs and other forms of treatment ${ }^{11}$. In order to achieve such goal, medical education regarding MS needs to improve ${ }^{12}$, and also the knowledge on how the disease affects the population of our country needs to be enhanced.

Although the prevalence of the disease in the city of Santos is relatively low, it is within the expected values for the region ${ }^{3}$. These values are similar to those registered in São Paulo ${ }^{13}$ and other cities of Brazil, which have been presented in scientific meetings without specific publications ${ }^{5}$. It is however noticeable that our patients with confirmed MS belong to a population of better socioeconomic level, which probably leads to better health care. Patients of lower socio-economic background may have less access to specialized medical care, and therefore may not have been properly diagnosed. The high prevalence of low levels of disability in our patients also suggests that individuals with greater disability are not being diagnosed as MS cases. Taking these facts into consideration, it is possible that the real prevalence of MS in the city of Santos is somewhat higher than what is presented here.

\section{Acknowledgments}

We thank the regional Association of Patients with Multiple Sclerosis (APEMBS) for the help in locating patients who were not registered at the Reference Center. The authors are grateful to all neurologists and neurosurgeons working in Santos for essential help in collecting these data.

\section{References}

1. Poser CM, Paty DW, Scheimberg L, McDonald WI, et al. New diagnostic criteria for multiple sclerosis: guidelines for research protocols. Ann Neurol 1983; 13: 227-31.

2. Noseworthy JH, Lucchinetti C, Rodriguez M, Weinshenker BG. Multiple Sclerosis. N Engl J Med 2000; 343: 938-52.

3. Rosati G. The prevalence of multiple sclerosis in the world: an update. Neurol Sci 2001; 22:117-39.

4. Disponível em www.lactrims.info [acessado em 30 de agosto de 2006]

5. Disponível em www.bctrims.org.br [acessado em 30 de agosto de 2006]

6. Brinar VV. The differential diagnosis of multiple sclerosis. Clin Neurol Neurosurg 2002; 104: 211-20.

7. Farrell R, Heaney D, Giovannoni G. Emerging therapies in multiple sclerosis. Expert Opin Emerg Drugs 2005; 10: 797-816.

8. Poser CM, Paty DW, Scheinberg L, McDonald WI, Davis FA, Ebers GC, Johnson KP, Sibley WA, Silberberg DH, Tourtellotte WW: New diagnostic criteria for MS: guideline for research protocols. Ann Neurol 1983; 13: 227-31.
9. McDonald WI, Compston A, Edan G, Goodkin D, Hartung HP, Lublin FD, McFarland HF, Paty DW, Polman CH, Reingold SC, Sandberg-Wollheim M, Sibley W, Thompson A, van den Noort S, Weinshenker BY, Wolinsky JS. Recommended diagnostic criteria for multiple sclerosis: guidelines from the International Panel on the diagnosis of multiple sclerosis. Ann Neurol 2001; 501: 121-7.

10. Freedman MS, Patry DG, Grand'Maison F, Myles ML, Paty DW, Selchen DH. Treatment optimization in multiple sclerosis. Can J Neurol Sci 2004; 31:157-68.

11. Montalban X. The pros and cons of early treatment of relapsing forms of multiple sclerosis. J Neurol 2004; 251 (S4): 30-4.

12. Fieschi C, Onesti E, Tomassini V. Medical education and MS: getting the training right. Int MS J2005; 12: 21-31.

13. Callegaro D, Goldbaum M, Moraes L, Tilbery CP, Moreira MA, Gabbai AA, Scaff M. The prevalence of multiple sclerosis in the city of Sao Paulo, Brazil, in 1997. Acta Neurol Scand 2001; 104: 208-13.

Recebido em: 19/09/06 Versão final reapresentada em: 25/08/07 Aprovado em: 27/08/07 